\title{
International Students Reported for Academic Integrity Violations: Demographics, Retention, and Graduation
}

\author{
Barry Fass-Holmes \\ University of California, San Diego, USA
}

\begin{abstract}
How many international students are reported for academic integrity violations (AIV), what are their demographics, and how do AIV sanctions affect their retention and/or graduation? Descriptive statistical analyses showed that the number of internationals reported for AIVs at an American West Coast public university increased almost six-fold between academic years 2009-10 and 2013-14. However, that number represented less than $7.5 \%$ of these students' total enrollment. Among reported ones, undergraduates outnumbered graduate students, males outnumbered females, Chinese outnumbered other nationalities, Economics majors outnumbered other majors, and the most common AIV was exam misconduct. More than half who were reported and suspended for AIVs graduated and/or were retained. These findings' administrative, policy, and theoretical implications are discussed.
\end{abstract}

Keywords: academic dishonesty, academic integrity, cheating, engagement, graduation, international students, retention, satisfaction

Recent reports in the mainstream media have called attention to "pervasive" cheating by American universities' international applicants (Nylander, 2015). These reports allege that applicants from Asian countries submit fraudulent standardized test scores (including tests of English proficiency), doctored transcripts, and/or falsified letters of recommendation (Lu \& Hunt, 2015; Nylander, 2015; Redden, 2015). If these allegations are correct, they could have serious implications for American universities' admissions policies which are intended to ensure that only truly qualified applicants (especially regarding their English proficiency) are offered admission. 
Mainstream media reports also include allegations of widespread cheating by international students attending American universities. For example, Qi (2015) reported that about 8,000 Chinese students recently were expelled from American universities due to poor grades and cheating. Although this number seemed alarming, it represented a relatively small fraction of the total number of Chinese students attending American universities-274,439 during academic year 2013-14 and 304,040 during 2014-15 (Institute of International Education, 2015a). Nevertheless, the 8,000 expulsions could lead American universities to implement additional programs and/or services promoting these students' retention and graduation which, in turn, would result in increased workload and/or costs for faculty, staff, and administrators (Alschuler \& Blimling, 1995; Whitely \& KeithSpiegel, 2001).

These media reports of cheating by international applicants and enrolled international students should prompt research studies to systematically and empirically determine its actual extent. One recent study examined five factors, including international student status, that might be expected to predict rates of reported cheating by undergraduates (Bertram Gallant, Binkin, \& Donohue, 2015). The study provided evidence that international student status was a risk factor for cheating at an American West Coast public university (hereafter referred to as "the University") which has been recognized for its excellence in academics and research (U.S. News and World Report, 2015). Specifically, an adjusted odds ratio analysis of the University's reported academic integrity violations (AIV) during the five most recent academic years revealed that international students were more than twice as likely to have an AIV as domestic counterparts. Bertram Gallant et al. (2015) therefore suggested that international students 1) were "particularly vulnerable" to cheating (p. 226), 2) needed to be made more aware of what constituted cheating, and 3) should be educated about the consequences of their cheating.

An alternative interpretation of the above finding is that international students' odds ratio for having a reported AIVs could have been related to annual increases in international students' enrollment. Like many American postsecondary institutions (especially public ones), the University has enrolled increasing numbers of international students during the academic years since the great recession of 2008 (Dorado \& FassHolmes, 2016). An increase in international students' total enrollment might have been accompanied by a proportional increase in these students' reported incidence of cheating; i.e., the increased incidence of reported AIV could have been a side effect of enrollment growth rather than a characteristic of international students. A precedent does exist for hypothesizing such a proportional relationship-the University's academically struggling international undergraduates have increased in 
number proportionally to such students' enrollment numbers (Fass-Holmes \& Vaughn, 2014).

The present research study's primary goal was to test the hypothesis that the University's reported AIVs for international students increased proportionally to their enrollment numbers during the five most recent academic years. If this hypothesis were confirmed, it would suggest that increases in reported cheating were attributable to enrollment growth in addition to, or possibly rather than, international student status. An additional goal was to demographically characterize international students reported for AIVs by quantitatively analyzing their education level (undergraduate vs. graduate), gender, home country, major field, and type of AIV. This analysis could serve as a model for future studies of AIVs at other universities to determine the present findings' degree of generalizability. It also could facilitate data-driven pedagogical, administrative, and/or programming decisions for controlling international students' cheating and for promoting their retention and graduation rates.

\section{LITERATURE REVIEW}

\section{International student enrollment and academic achievement}

Despite the media's aforementioned reports of "pervasive" cheating by international applicants (Nylander, 2015), American universities generally have admitted and enrolled increasing numbers of international students during academic years following the great recession of 2008 . According to the Institute of International Education's (IIE) annual Open Doors data, international students' total enrollment in the United States increased by $2.9 \%$ in $2009-10,4.7 \%$ in $2010-11,5.7 \%$ in $2011-12,7.2 \%$ in 2012-13, and 8.1\% in 2013-14 (IIE, 2015b). New (i.e., first-time) enrolled international students increased by $1.3 \%$ in $2009-10$, $5.7 \%$ in $2010-11$, $6.5 \%$ in 2011-12, 9.8\% in 2012-13, and 7.7\% in 2013-14 (IIE, 2015c).

Public universities have contributed to these annual increases in international students' total and first-time enrollment in America. For example, the University's total enrollment of international undergraduates increased by $21.2 \%$ in $2010-11,46.9 \%$ in $2011-12$, 31.0\% in 2012-13, and 20.5\% in 2013-14 (Dorado \& Fass-Holmes, 2016). Corresponding values for the University's first-time international students were $123.2 \%$ in AY 2010-11, 117.5\% in 2011-12, 92.2\% in 2012-13, and 20.2\% in 2013-14 (Dorado \& Fass-Holmes, 2016). Increases in American public universities' international enrollments and admissions were a consequence of the $23 \%$ average reduction in state funding per student since 2008 (Mitchell, Palacios, \& Leachman, 2014). By enrolling more international applicants whose tuition and fees were higher than domestic counterparts', American public universities essentially used international students to compensate for 
the reduction in state funding (Cantwell, 2015).

Students from China comprised increasing percentages of internationals attending American universities during the past five years. Chinese students accounted for $18.5 \%$ of international enrollment nationwide in 2009-10 (IIE, 2015d) and 31.0\% in 2013-14 (IIE, 2015e), and each year's percentage ranked first among nationalities. At the University, Chinese undergraduate enrollment ranked second to South Korean in 2009-10 and 2010-11 but ranked first in subsequent academic years (Dorado \& Fass-Holmes, 2016). They also accounted for 41.7 and $49.5 \%$ of the University's total international undergraduates enrolled in 2012-13 and 2013-14, respectively (Fass-Holmes \& Dorado, unpublished data).

The University's increase in international student enrollment described above has led to heightened concern among administrators, faculty, and staff that their international students collectively struggle academically (term grade point averages below 2.0 [C]). The concern about international students' academic performance has heightened despite historically strong support through a wide range of programs and services (Fass-Holmes \& Vaughn, 2014) intended to optimize these students' academic and social integration, and to promote their retention and graduation (Tinto, 1975). Programs include a mandatory orientation for all newly admitted international students that has a segment on academic integrity. This concern that the University's international students collectively struggle academically has been disconfirmed, however. Research studies have shown instead that the number of struggling international undergraduates has increased proportionally to their enrollment numbers (Fass-Holmes \& Vaughn, 2014, 2015).

\section{Cheating}

International students' increasing enrollment and academic performance at American universities are important to the present study because of the potential escalation of reported AIVs given these students' allegedly "pervasive" cheating (Nylander, 2015). International students might have a higher risk of reported AIVs than domestic counterparts (Bertram Gallant et al., 2015) due to challenges that the former experience uniquely. Their unique challenges include (but are not limited to) acculturative stress, cultural barriers, English language weakness, mandatory compliance with immigration regulations, and lack of familiarity with American academic integrity standards and/or teaching methods (Dorado \& Fass-Holmes, 2016; Hanassab \& Tidwell, 2002; Sherry, Thomas, \& Chui, 2010).

Student cheating (also referred to as academic dishonesty or misconduct; Bertram Gallant, 2008) has been the subject of numerous 
studies in the educational research literature dating back to the early 1900s (Bertram Gallant, 2008; Callahan, 2010; Wideman, 2008). Many of these studies can be organized into one of at least three categories: analyses of faculty members', administrators', and/or students' perceptions and/or attitudes about cheating; determinations of the prevalence of cheating among students; and investigations into causes of cheating. Further research on the first and third of these categories could provide critical information for guiding universities' efforts to control cheating, while the second would help in understanding the scope of effort needed to exercise control.

The educational research literature on student cheating has referenced various guiding theories. Many of these theories originated from disciplines other than International Education, including (but not limited to) Criminology, Economics, Ethics, and Psychology. For example, DiPietro's (2010) comparative review of the extant literature on student cheating referenced five common theoretical frameworks-deterrence theory (the frequency of cheating is inversely related to the magnitude of its punishments), rational choice theory (students decide to cheat on the basis a logical cost-benefit analysis), neutralization theory (cheating happens when students conclude that it is morally inoffensive rather than wrong), planned behavior theory (situations which provide an opportunity to cheat without getting caught are what lead to cheating), and situational ethics theory (students' decision whether to cheat is based upon unique considerations under circumstances which ordinarily do not apply). Murdock \& Anderman (2006) used psychological concepts from self-efficacy theory (students' judgments about their ability to accomplish a desired outcome), goal theory (students' constructed notions about education's purpose), expectancy value (a cost-benefit analysis of achieving an educational goal guides students' behavior), and intrinsic motivation theory (a genuine desire to understand is a high intrinsic value; performance and ego goals represent low intrinsic value) to organize the educational research literature on cheating.

One weakness of these theoretical frameworks in guiding research on cheating, however, is their limited efficacy in predicting differences among international students (DiPietro, 2010; Murdock \& Anderman, 2006). For example, the finding that undergraduates studying business or economics in Eastern European or Central Asian countries have a relatively lower standard of honesty than American counterparts (Grimes, 2004; Lupton, Chapman, \& Weiss, 2000) would be difficult to predict or explain using the aforementioned theoretical frameworks (DiPietro, 2010; Murdock \& Anderman, 2006). This weakness in the theoretical frameworks, in turn, could limit their effectiveness in guiding the development and implementation of strategies to control cheating's prevalence (which has persisted at an unsatisfactorily high level in higher education despite administrators', faculty members', and staff members' efforts to control it 
[Lang, 2013; McCabe, Butterfield, \& Treviño, 2012]).

Theoretical frameworks on cheating have difficulty predicting or explaining international students' cheating (at least in part) because of factors which have little (if any) bearing on domestic students but do influence internationals attending American universities. Such factors include (but are not limited to) international students' feelings of isolation and/or alienation (Bista, 2011; Hayes \& Introna, 2005; Whitley, 1998), friendships and involvement with groups of other students from the same country (Hayes \& Introna, 2005), collectivist cultural backgrounds (McCabe, Feghali, \& Abdallah, 2008), and lack of familiarity with American educational standards for academic integrity (Bista, 2011; Lupton et al., 2000; Mori, 2000).

An alternative to these theoretical frameworks is Bertram Gallant's (2008) organizational strategy that addresses cheating by focusing on teaching and learning rather than students' behavior and character. This strategy shifts universities' efforts from policing and deterring student cheating to ensuring student learning.

The teaching and learning strategy for enhancing integrity in academic work originates out of more broad-based strategies to improve learning in postsecondary education settings...The strategy primarily suggests that the integrity of students' academic work is intimately linked to the learning environment...Thus, the strategy attends not just to the rule compliance or integrity of the individual student or student population but to the integrity of the institutional environment as a whole. (Bertram Gallant, 2008, p. 88)

Researchers have found that students who admit to cheating perceive their classroom environment to be "less personalized, less involving, less cohesive, less satisfying, less task oriented, and less individualized" (Pulvers and Diekhoff, 1999, p. 495). Thus, rather than convincing students to stop cheating, the goal of the teaching and learning strategy is to foster a learning-oriented environment that will motivate students to engage in the course material. (Bertram Gallant, 2008, p. 89)

Although the teaching and learning strategy (like the aforementioned theoretical frameworks) does not originate from the discipline of International Education, it does yield the following predictions which can be tested. 1) If academic integrity is linked to an environment focused on teaching and learning, then universities which adopt this strategy should experience a generalized steady-state or declining prevalence of cheating over time. 2) A steady-state or declining prevalence of cheating 
should be exhibited by international students. 3) Alternatively, if international students' prevalence of cheating inherently exceeds domestic students', an enhancement in the teaching and learning strategy which specifically targets international students should mitigate their prevalence of cheating. The first prediction would require a study that includes domestic students, and the third would require an evaluation, both of which were beyond the present research study's scope and goals. The second prediction, however, is addressed in this research study.

\section{Retention, graduation, engagement, and satisfaction}

Cheating has consequences for individual students' retention and graduation (and for universities' retention and graduation rates) when suspension and/or expulsion are employed as sanctions. Retention (annual progression through students' program of study) and graduation (completion of their program of study) are considered key indicators of student success (Kuh, Kinzie, Buckley, Bridges, \& Hayek, 2006; Therriault \& Krivoshey, 2014) and have been used as accountability indicators for public universities (Cook \& Pullaro, 2010; Gold \& Albert, 2006). These two indicators of student success and university accountability have taken on increasing administrative importance because they have attracted the attention of elected officialsincluding the United States' (U.S.) President and Vice President-who have called for American universities to improve their students' retention and graduation rates (Asimov \& Gutierrez, 2015; Asmussen, 2011; Obama, 2009; U.S. Department of Education, 2011).

Student retention and/or graduation are/is interrupted and/or prevented by suspensions and expulsions, respectively (by definition). These sanctions nevertheless have been employed (in combination with Bertram Gallant's [2008] organizational strategy of focusing on teaching and learning) at the University which is the subject of the present study. To determine the extent to which the University's AIV sanctions affect its international students' progression and completion, the present study measured the percentage who were suspended and then graduated and/or were retained after being reported for an AIV. (Note: because the University bars expelled students from returning to complete their degree, their retention and graduation numbers are zero.)

Cheating also has consequences for students' engagement when suspension and/or expulsion are employed as sanctions. Student engagement is interrupted and/or prevented by suspensions and expulsions, respectively (by definition). The concept of engagement, as originally used and intended in organizational behavior research, refers to workers expressing themselves physically, cognitively, and emotionally while performing their job (Kahn, 1990). This concept, as subsequently used and intended in educational research, is essentially synonymous with "involvement" (Tinto, 2007) and 
refers to students bonding to their school cognitively, affectively, behaviorally, and as action agents who are committed and motivated to learn (Veiga et al., 2012). Many definitions of student engagement exist in the educational research literature, including the National Survey of Student Engagement's (2015) definition-students' investment in their studies and educational activities, and their institutions' investment in courses and other learning opportunities. Engagement is relevant to the present study because research has shown that it is essential for student retention (Astin, 1984; Tinto, 2007). Numerous studies have shown that undergraduates' learning is enhanced when they are educationally engaged/involved (e.g., Kuh, 2003; Zhao, Kuh, \& Carini, 2005).

Cheating additionally has consequences for students' satisfaction when suspension and/or expulsion are employed as sanctions. The concept of satisfaction refers to the quality of experience with instruction, curriculum, faculty, other students, the administration, and facilities (Astin, 1993). This concept is pertinent to the present study because previous research has shown that it too is essential for student success (Astin, 1993). Student satisfaction is diminished by suspension and expulsion (by definition), and is positively associated with retention which, in turn, is positively associated with academic success (Elliott \& Healy, 2001; Korobova \& Starobin, 2015; Schertzer \& Schertzer, 2004).

\section{RESEARCH METHOD}

The present research study's prime goal was to test the hypothesis that the number of international students reported for AIVs at the University increased proportionally to their enrollment numbers during the five most recent academic years. Its second goal was to demographically characterize international students reported for AIVs by quantitatively analyzing their education level (undergraduate vs. graduate), gender, home country, major field, and type of AIV. Demographic characterizations of cheating students have been published previously (e.g., Bertram Gallant et al., 2015; Whitley, 1998). However, the educational research literature lacked demographic analyses of international students who cheated (especially analyses in the post-great recession era of booming international enrollment at American universities; IIE, 2015b). Consequently, the present study included a demographic analysis of reported international students to facilitate administrative decision-making about programs and services for these students.

The following questions were addressed in the present study. 1) How many and what percentage of the University's international students were reported for AIV during the five most recent academic years for which data were available? 2) Did the number of international students reported for AIVs increase across these academic years, and if so was the increase independent of, or was it proportional to, the increase in total international enrollment? 3) What types 
(allegations) of AIVs were reported? 4) How many and what percentage of these students were sanctioned (suspension; expulsion) for their AIVs? 5) What were their demographic characteristics? 6) What percentage of these sanctioned students subsequently graduated and/or were retained? The present study's objectives did not include assessment of student learning outcomes or evaluation of the University's programs and services which address cheating.

\section{Participants, data collection, and analyses}

Demographic data for international students attending the University during at least one of the academic years between 2009-10 and 2013-14, inclusive, were extracted from its student information system using structured query language programs (Vaughn, Bergman, \& Fass-Holmes, 2015). The resulting records included all internationals (excluded American citizens, amnesty-seekers, applicants for permanent residency, asylees, permanent residents, refugees, and undocumented individuals except where noted otherwise; this was done for consistency with U.S. Government regulations' definition of non-immigrant international students [U.S. Department of State, n.d.]). These records contained each student's unique ID number plus values for the demographic variables of interest-education level, gender, citizenship country, and major. They were organized in a spreadsheet file and linked with counterparts extracted from the University's academic integrity database that contained the types of AIV allegations and sanctions in addition to ID number (Bertram Gallant et al., 2015). Confidentiality was ensured by following procedures approved by the University's Institutional Review Board; they included encrypting and statistically analyzing the file's contents on a secured computer.

Descriptive statistical analyses in spreadsheet software consisted of computing counts and percentages disaggregated by the aforementioned demographic variables. These analyses included undergraduates and graduate students, degree-seekers (F-1 visa), non-degree students (J-1 visa), and students with any other visa type listed in the Directory of Visa Categories (U.S. Department of State, n.d.) except where indicated otherwise in the Results section. $\mathrm{Z}$ tests for population proportions (http://www.socscistatistics.com/tests/ztest/Default2.aspx) were performed to determine whether the increase in international students reported for AIVs was independent of, or proportional to, the increase in total international enrollment across academic years. This methodology's primary limitation was that it focused on a single American university. Generalizability of the present results to other domestic or foreign higher education institutions was not determined. However, the analyses could serve as a model for other American higher education institutions to replicate and use in data-driven decision making about admissions and academic integrity policies, support programs, and services for international students. 


\section{RESULTS}

\section{Reported AIVs}

Table 1 shows the total number of AIVs reported (including domestic students) and the corresponding value for international students. The latter value increased almost six-fold over the five academic years in this study, thereby replicating and confirming the findings of Bertram Gallant et al. (2015). Additionally, the percentage of total reported AIVs accounted for by international students is included in Table 1 . This value was $8.7 \%$ and $10.5 \%$ of all AIVs in $2009-10$ and $2010-11$, respectively. The percentage then increased in the next three academic years peaking at $37 \%$ in 2013-14. Collapsing the data over the five academic years, international students accounted for one-fifth of the University's reported AIVs.

Table 1: Numbers (N) and Percentages of International Students Reported for Academic Integrity Violations (AIVs) in Five Academic Years

\begin{tabular}{lcccccc}
\hline Reported for AIVs & $2009-10$ & $2010-11$ & $2011-12$ & $2012-13$ & $2013-14$ & TOTAL \\
\hline International students (N) & 35 & 65 & 81 & 157 & 203 & 541 \\
All students (N) & 402 & 617 & 573 & 588 & 546 & 2,726 \\
International \% of all & 8.7 & 10.5 & 14.1 & 26.7 & 37.2 & 19.8 \\
\hline
\end{tabular}

\section{Education level}

Figure 1 shows the numbers and percentages of degree-seeking (F-1 visa) and non-degree (J-1 visa) international undergraduates (including firsttime freshmen, transfers, and exchange visitors) and graduate students reported for AIVs (data for students with other visa types are available from the author upon request). Undergraduates reported for AIVs outnumbered graduate student counterparts by about seven- to ten-fold over the five academic years. The number at both education levels increased by six- or seven-fold from 2009-10 ( $\mathrm{n}=32$ undergraduates, 3 graduate students) to 2013-14 ( $\mathrm{n}=182$ undergraduates, 21 graduate students). However, the increase of reported undergraduates expressed as a percentage of the total international undergraduate enrollment was about two-fold from 2009-10 (3.7\%) to 2013-14 (6.7\%); the corresponding increase of reported graduate students was five-fold ( $0.3 \%$ to $1.5 \%)$.

To determine whether the year-to-year increase in the University's number of internationals reported for AIVs was proportional to the year-toyear increase in the total international enrollment, $Z$ tests for population proportions were performed on the undergraduates' data (graduate students' 
data were excluded because their numbers reported for AIVs were so small, as shown in Figure 1; results including these students' data are available from the author upon request). These tests showed that the increases in AIVs between 2009-10 and 2010-11 $(Z=-2.061, p=.039)$ and between 2011-12 and 2012-13 $(Z=-2.736, p=.0061)$ were statistically significant $(p<.05)$, while the other two year-to-year comparisons were not $(Z=0.8885, p=.37$; and $Z=0.7353, p=.46$, respectively).
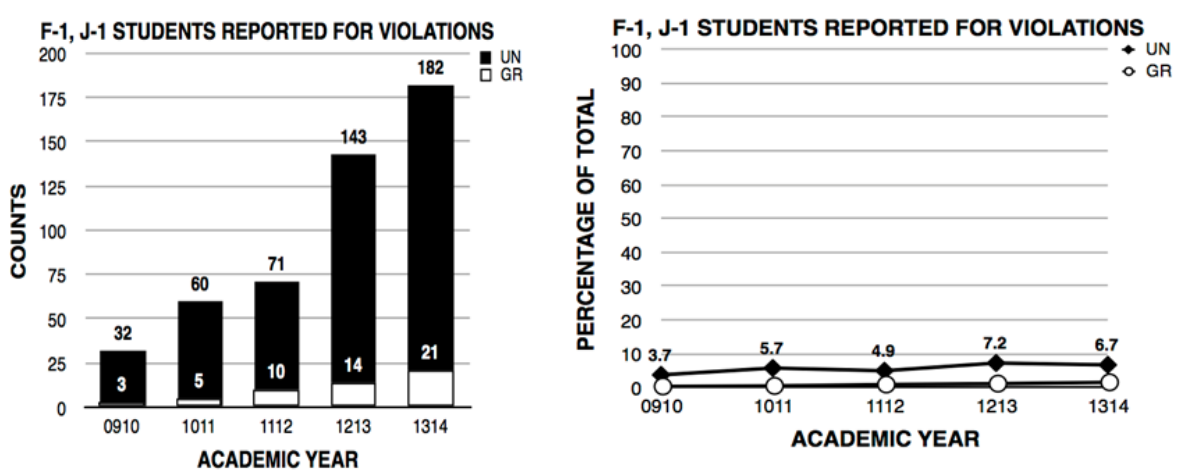

Figure 1. The numbers of degree-seeking (F-1) and non-degree (J-1) undergraduates (filled bars; UN) and graduate students (open bars; GR) reported for violations are shown in the left graph; corresponding percentages (filled diamonds, UN; open circles, GR) are shown in the right graph. Percentages are relative to the total number of international undergraduates and graduate students, respectively. Although the numbers of reported internationals increased, the percentages were essentially flat.

\section{Sanctions for reported AIVs}

The percentages of the University's degree-seeking (F-1 visa) and nondegree (J-1 visa) students, disaggregated by education level, who were sanctioned (suspended or expelled) for reported AIVs are shown in Figure 2 (data for students with other visa types are available from the author upon request). This figure shows two types of percentage; one is relative to the total number of international undergraduates or graduate students who were reported for AIVs, the other is relative to the University's total enrollment of international undergraduates or graduate students. Over $60.0 \%$ of the reported international undergraduates and graduate students were sanctioned, and up to $5.0 \%$ of all enrolled international undergraduates and graduate students were sanctioned (Figure 2). The number of reported and sanctioned international undergraduates increased from 29 in academic year 2009-10 to 136 in 201314; the corresponding numbers for graduate student counterparts were 2 and 17. 


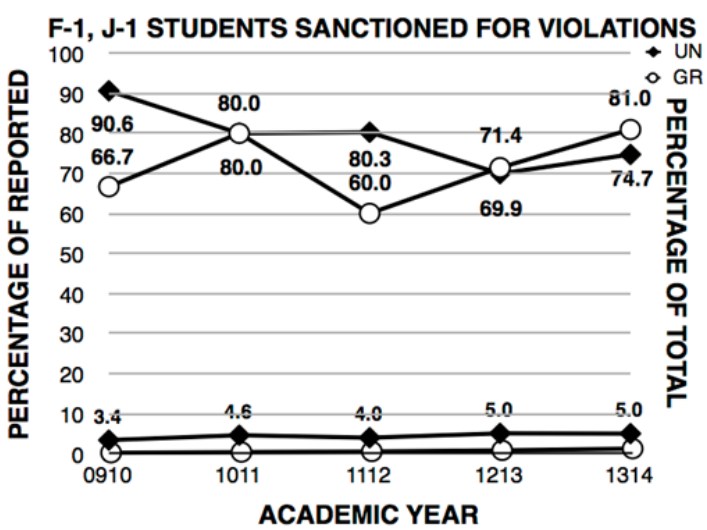

Figure 2. The percentages of international undergraduates (filled diamonds; UN) and graduate students (open circles; GR) sanctioned for violations are represented in the upper lines relative to the number of international students who were reported (left $\mathrm{Y}$-axis), and in the lower ones relative to the total numbers of international students (right $\mathrm{Y}$-axis).

\section{Types of AIV allegations}

Exam misconduct, plagiarism, and homework misconduct (as defined by Bertram Gallant et al., 2015) were the three most frequent types of AIV allegations, as shown in Figure 3. Exam misconduct AIVs accounted for $36.8 \%$ of the University's total number of reports in academic year 2009-10 (14 out of 38) and 52.0\% in 2013-14 (117 out of 225). The corresponding values were $44.7 \%$ (17 out of 38) and 26.2\% (59 out of 225) for plagiarism, and 15.8\% (6 out of 38) and 18.7\% (42 out of 225) for homework misconduct.

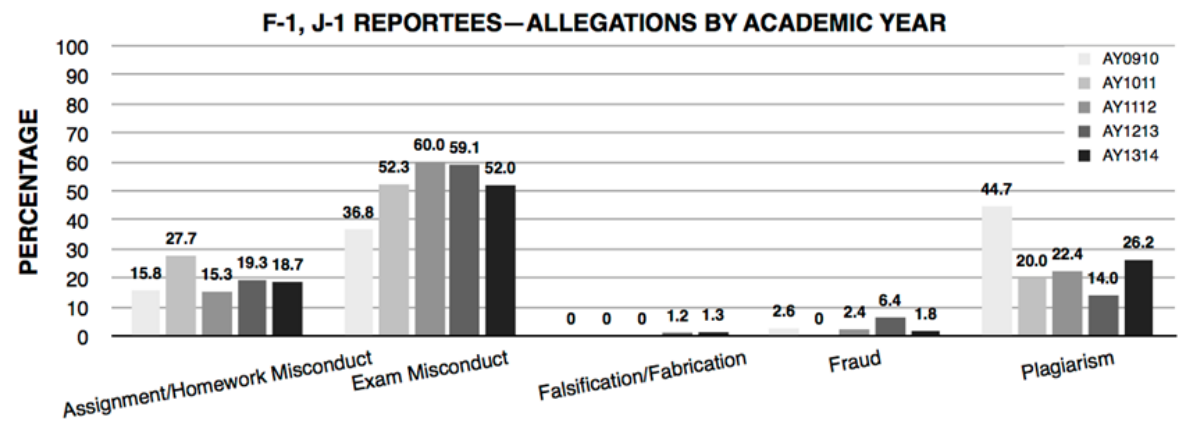

Figure 3. The percentage of each type of allegation (as defined by Bertram Gallant et al., 2015 ) is shown relative to the total number of degree-seeking (F-1 visa) and non-degree (J-1 visa) students (undergraduates, graduate students, and exchange visitors combined) who were reported for violations during each of the five academic years (AY) in this study.

\section{Gender}

Males outnumbered females among the University's enrolled international students (Fass-Holmes \& Vaughn, 2014), and this trend also occurred among those reported for AIVs as shown in Figure 4. At the 


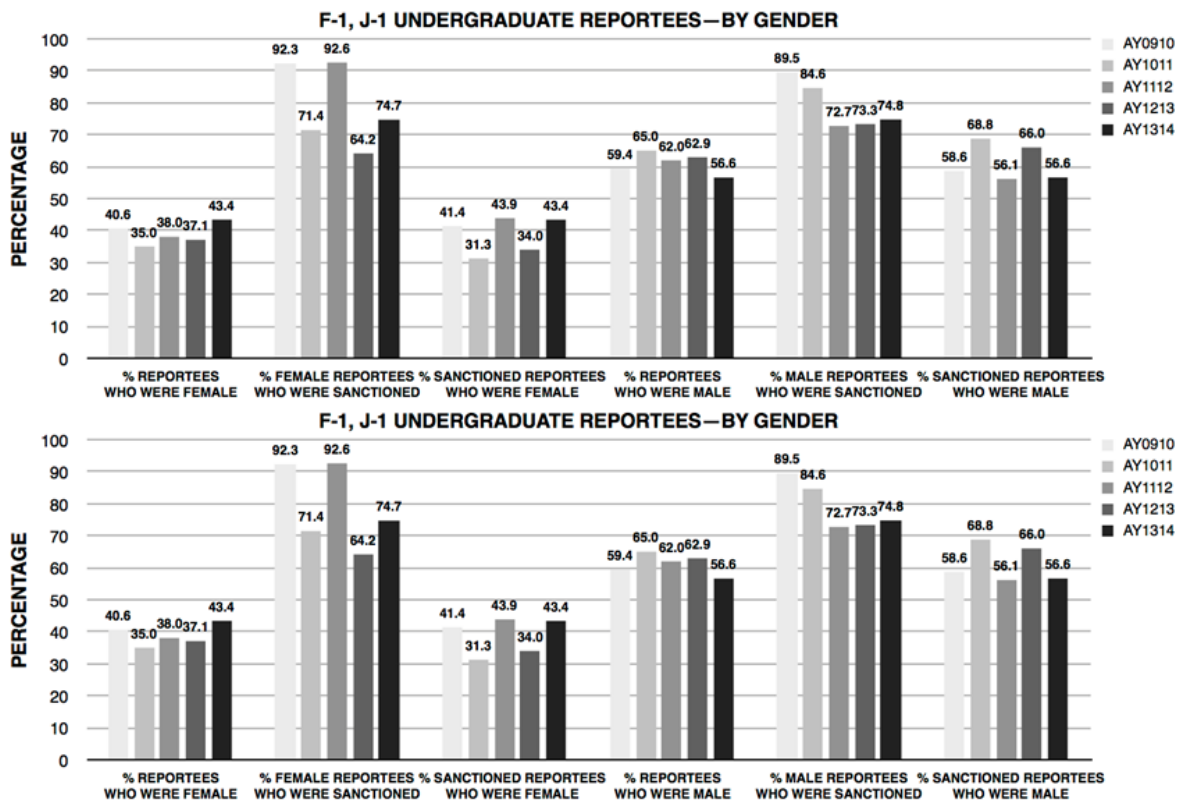

Figure 4. The percentages of reported or sanctioned degree-seeking (F-1 visa) and nondegree (J-1 visa) undergraduates (top graph) and graduate students (bottom) are disaggregated by gender for each of the five academic years (AY). The first three sets of bars in each graph show percentages for female international students, the second three sets show corresponding values for male counterparts.

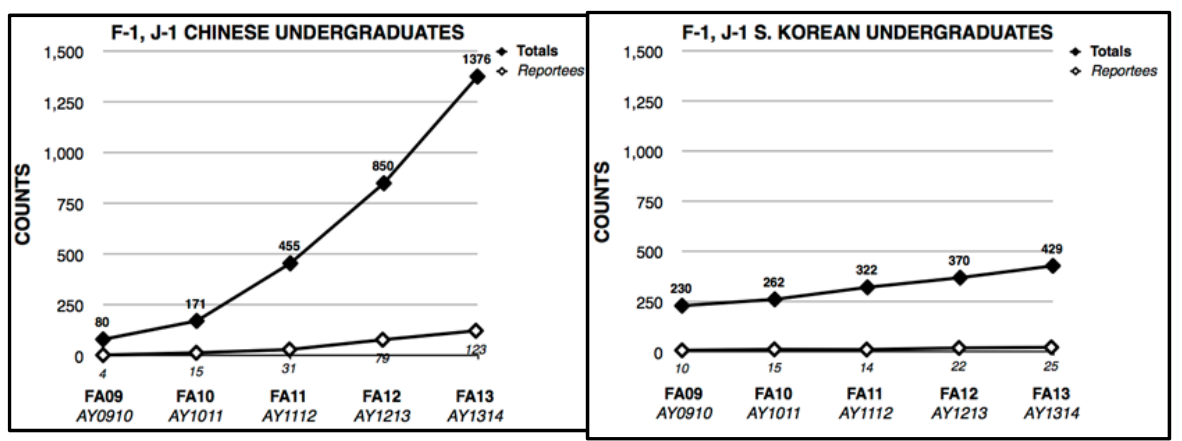

Figure 5. The numbers of Chinese (left) and South Korean (right) undergraduates reported for academic integrity violations (open diamonds) are shown in contrast with the corresponding enrollment numbers (filled diamonds). Abbreviations: FA09=fall term 2009; FA10=fall term 2010; FA11=fall term 2011; FA12=fall term 2012; FA13=fall term 2013; AY=academic year

undergraduate level, roughly $60 \%$ of the internationals reported for AIVs during the five academic years in this study were male and a similar percentage of the sanctioned internationals was male, also. The percentage 
of female international undergraduates reported and sanctioned for AIVs was generally comparable to the corresponding percentage of male counterparts. At the graduate level, gender disaggregated percentages who were reported or sanctioned showed inconsistent patterns (likely due to the small numbers of these students as shown in Figure 1), consequently rendering generalizations tenuous.

\section{Citizenship country}

China and South Korea were the top two citizenship countries of the University's international undergraduates (Fass-Holmes \& Vaughn, 2014). Chinese undergraduates accounted for $9.1 \%$ of the University's total population of international undergraduates in fall 2009 (79 out of 865) and $50.3 \%$ in fall 2013 (1,374 out of 2,732), and they accounted for $12.5 \%$ of the University's total number of international undergraduates reported for AIVs in fall 2009 (4 out of 32) and 67.6\% in fall 2013 (123 out of 182). The corresponding values for South Korean undergraduates were $26.6 \%$ (230 out of 865 ) and $15.7 \%$ (429 out of 2,732), and 31.3\% (10 out of 32) and 13.7\% (25 out of 182).

As shown in Figure 5, Chinese undergraduates reported for AIVs in fall 2009 amounted to $5.0 \%$ of enrolled Chinese undergraduates (4 out of 80 ) and 8.9\% in fall 2013 (123 out of 1376). The corresponding values for South Korean undergraduates were 4.3\% (10 out of 230) and 5.8\% (25 out of 429).

China and South Korea were the number one and three citizenship countries, respectively, of the University's international graduate students (FassHolmes \& Dorado, unpublished data). Chinese graduate students accounted for $24.0 \%$ of the University's total population of international graduate students in fall 2009 (246 out of 1,027) and 38.4\% in fall 2013 (535 out of $1,395)$, and they accounted for $66.7 \%$ of the University's total number of international graduate students reported for AIVs in fall 2009 (2 out of 3), $71.4 \%$ in fall 2013 (15 out of 21). The corresponding values for South Korean graduate students were $15.1 \%$ (155 out of 1,027) and 9.9\% (138 out of 1,395 ), and $0 \%$ ( 0 out of 3 ) and $4.8 \%$ (1 out of 21 ).

Chinese graduate students reported for AIVs in fall 2009 amounted to $0.8 \%$ of enrolled Chinese graduate students (2 out of 246) and $2.8 \%$ in fall 2013 (15 out of 535). The corresponding values for South Korean graduate students were $0.0 \%$ ( 0 out of 155 ) and $10.9 \%$ (15 out of 138 ).

\section{Major}

The majors with the highest percentages of international students (undergraduates and graduate students) reported for AIVs varied to a limited degree across the five academic years in this study, as shown in Figure 6. A prominent consistency was that Economics had the highest percentage (25- 
$35 \%$ ) of internationals reported for AIVs in each academic year-9 out of 35 in 2009-10, 23 out of 65 in 2010-11, 22 out of 81 in 2011-12, 45 out of 157 in 2012-13, and 52 out of 203 in 2013-14. Computer Science and Economics-Management Science were in the top five for four of the five academic years, and Communications and Electrical Engineering were in the top five for three of the five academic years. A total of 10 of the top 25 majors, summing over the five academic years, were science, technology, engineering, or mathematics.

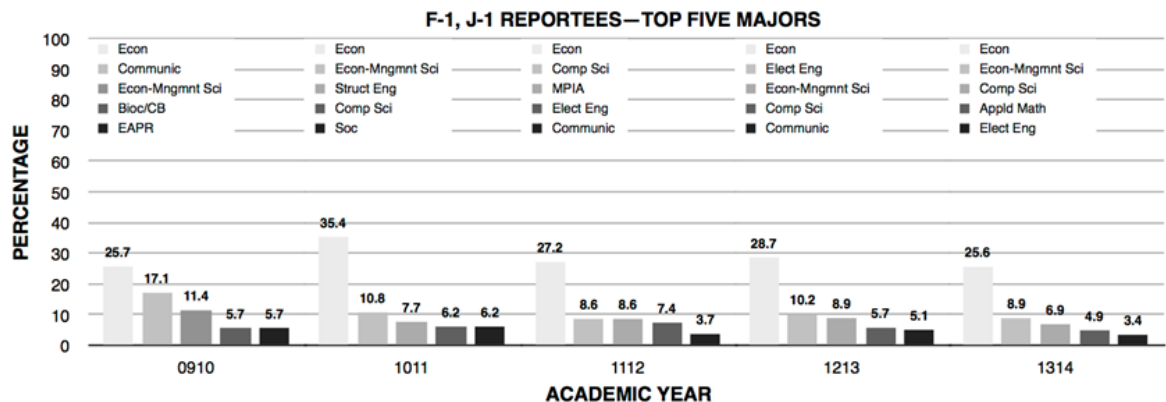

Figure 6. The top five majors of international students reported for academic integrity violations. Abbreviations: Econ=Economics; Communic=Communications; Econ-Mngmnt Sci=Management Science; Biol/CB=Cell Biology; EAPR=exchange visitor; Struct Eng=Structural Engineering; Comp Sci=Computer Science; Soc=Sociology; MPIA=Master's in Pacific and International Affairs; Elect Eng=Electrical Engineering; Appld Math=Applied Mathematics

\section{Retention and graduation}

Table 2 shows the numbers $(\mathrm{N})$ and percentages of the University's degree-seeking (F-1 visa) and non-degree (J-1 visa) undergraduates and graduate students who were suspended for AIVs during the five academic years in this study and subsequently graduated and/or were retained. Some of these students (especially ones in the most recent academic years) had not graduated yet because too little time had passed for them to complete their degree requirements.

In Table 2, values for percentage in each row (except the last two) are relative to the preceding row's $\mathrm{N}$ values. Thus, the percentage of $\mathrm{F}-1$ and J-1 students reported for AIVs ranged from a low of 2.0\% (35 out of 1769 who were enrolled in classes at the University) in 2009-10 to a high of 5.0\% (203 out of 4084) in 2013-14. The percentage sanctioned for reported AIVs ranged from a low of $70.1 \%$ (110 out of 157 ) in 2012-13 to a high of $88.6 \%$ (31 out of 35) in 2009-10. The percentage suspended for AIVs ranged from a low of $11.5 \%$ (6 suspended out of 52 reported) in 2010-11 to a high of $30.2 \%$ (19 suspended out of 81 reported) in 2011-12. These suspended students' graduation rate, in turn, ranged from a low of $15.6 \%$ (5 out of 32) in $2013-14$ to a high of $83.3 \%$ (5 out of 6 ) in $2010-11$. The retention rate 
for these students decreased across the academic years in this study; only $25.0 \%$ (2 out of 8) who were suspended for an AIV in 2009-10 were not retained (the other 6 were retained and graduated), while $46.9 \%$ (15 out of 32) who were suspended for an AIV in 2013-14 were not retained (some or all of them potentially could have been retained in subsequent academic years, however). Expelled students' graduation rate was $0.0 \%$ because they were barred from returning to the University.

Table 2: Numbers $(\mathrm{N})$ and Percentages of International Degree-Seeking Students and Exchange Visitors Reported for Academic Integrity Violations in Five Academic Years: Retention and Graduation

\begin{tabular}{|c|c|c|c|c|c|c|c|c|c|c|}
\hline \multirow{2}{*}{$\begin{array}{l}\text { Internationals' } \\
\text { outcomes }\end{array}$} & \multicolumn{2}{|c|}{ 2009-10 } & \multicolumn{2}{|c|}{ 2010-11 } & \multicolumn{2}{|c|}{ 2011-12 } & \multicolumn{2}{|c|}{ 2012-13 } & \multicolumn{2}{|c|}{ 2013-14 } \\
\hline & $N$ & $\%$ & $N$ & $\%$ & $N$ & $\%$ & $N$ & $\%$ & $N$ & $\%$ \\
\hline enrolled & 1769 & 100 & 2105 & 100 & 2533 & 100 & 3177 & 100 & 4084 & 100 \\
\hline reported & 35 & 2 & 65 & 3 & 81 & 3 & 157 & 5 & 203 & 5 \\
\hline sanctioned & 31 & 89 & 52 & 80 & 63 & 79 & 110 & 70 & 153 & 75 \\
\hline suspended & 8 & 26 & 6 & 12 & 19 & 30 & 20 & 18 & 32 & 21 \\
\hline $\begin{array}{l}\text { suspended and } \\
\text { graduated }\end{array}$ & 6 & 75 & 5 & 83 & 9 & 47 & 9 & 45 & 5 & 16 \\
\hline $\begin{array}{l}\text { suspended and } \\
\text { retained, not yet } \\
\text { graduated }\end{array}$ & 0 & 0 & 0 & 0 & 2 & 11 & 2 & 10 & 12 & 36 \\
\hline not retained & 2 & 25 & 1 & 17 & 8 & 42 & 9 & 45 & 15 & 47 \\
\hline
\end{tabular}

\section{DISCUSSION AND CONCLUSIONS}

The present study was conducted to test the research hypothesis that the University's international students who were reported for AIVs increased proportionally to their enrollment numbers during the five most recent AYs. If this hypothesis were confirmed, it would suggest that increases in reported cheating were related to enrollment growth in addition to, or possibly rather than, international students' vulnerability to cheat (Bertram Gallant et al., 2015). An additional goal was to demographically characterize these students by quantitatively analyzing their education level (undergraduate vs. graduate), gender, home country, major field, and type of 
AIV. Cheating students' demographic characterizations have been reported in the educational research literature previously (e.g., Bertram Gallant et al., 2015; Whitley, 1998). However, such characterizations focused on domestic students and the literature lacked demographic analyses of international students who cheated (especially ones in the post-great recession era of booming international enrollment at American universities; IIE, 2015b). Consequently, the present study included such an analysis to facilitate administrative decision-making about programs and services to target the appropriate students.

To achieve the above two goals, the following five research questions were addressed. First, how many and what percentage of international students were reported for AIVs? Although the University's number of reported international undergraduates and graduate students increased almost six-fold from 2009-10 $(\mathrm{N}=35)$ to $2013-14(\mathrm{~N}=203)$ in the present study (thus replicating and confirming findings reported by Bertram Gallant et al., 2015), this increase additionally was in part proportional to the increase in the total number of enrolled international students as shown by statistical analyses. Importantly, the University's total number of international students reported for AIVs amounted to less than $7.5 \%$ of the total number who were enrolled. These findings indicated that AIVs were reported to a lesser degree than what would be expected if cheating were a vulnerability of international students.

Second, what types of AIVs were reported? Exam misconduct, plagiarism, and homework misconduct were the three most frequent AIV types allegedly committed by the University's international students. More than half of the reported AIVs were for exam misconduct in four of the five academic years, more than one-fifth were for plagiarism in four of the five academic years, and less than one-fifth were for homework misconduct in four of the five academic years. These findings suggested that faculty members and/or teaching assistants were more likely to detect and report AIVs for cheating on exams than for cheating related to term papers, projects, or homework assignments.

Third, how many and what percentage of reported international students were sanctioned for their AIVs? The number of such students ranged from a total of 31 out of 35 (almost 90\%) in 2009-10 to a total of 153 out of 203 (about 75\%) in 2013-14. These values represented a fivefold increase over the five academic years in the present study, and they indicated that international students who were reported for AIVs had a high probability of subsequently being suspended or expelled from the University. These consequences for reported AIVs therefore had serious implications for the affected international students' retention and graduation as discussed below.

Fourth, what were these reported international students' 
demographic characteristics? In general, a majority was male, the predominant nationality was Chinese, and a plurality majored in Economics. This finding paralleled the demographics of the University's international population (Dorado \& Fass-Holmes, 2016; Fass-Holmes \& Vaughn, 2014). It also could indicate that Economics faculty members and teaching assistants were more likely to detect and report cheating by male Chinese majors than cheating by other demographic groups such as female South Koreans; and that Economics faculty members and teaching assistants were more likely to detect and report cheating than their colleagues in other departments. Otherwise, the disparities between the reported AIVs among demographic characteristics observed in the present study would be difficult to predict or explain if international students (especially those who were not native English speakers) had a vulnerability to cheat.

Lastly, what percentage of internationals who were suspended for AIVs subsequently graduated and/or were retained? The majority of these students were retained, and almost half to three-quarters who had sufficient time to complete their degree requirements did graduate. This finding suggested that suspension for AIVs was a temporary, rather than longlasting, impediment to reported international students' completion of their program of study. However, because of the University's policy barring expelled student from returning, any international student reported for AIVs and expelled subsequently did not graduate and was not retained.

The present study's answers to the above five research questions, taken together, are consistent with the hypothesis that the number of the University's international students reported for AIVs was proportional to their total enrollment numbers during the five most recent AYs. These questions' answers additionally replicate and extend previous findings indicating that internationals students are vulnerable to cheating (Bertram Gallant et al., 2015). This interpretation of the present findings has implications for Bertram Gallant's (2008) organizational strategy that addresses cheating by focusing on teaching and learning and shifts universities' efforts away from policing and deterring student cheating, as discussed below.

Heightened concern among the University's administrators, faculty, and staff about widespread cheating by international students has accompanied concerns that these students collectively struggle academically (Fass-Holmes \& Dorado, unpublished observations; Fass-Holmes \& Vaughn, 2014, 2015). These concerns could be interrelated; anecdotal evidence indicates that administrators, faculty, and staff believe their international students collectively struggle academically due to English weakness and therefore collectively resort to cheating (Fass-Holmes \& Dorado, unpublished observations). The belief about international undergraduates' collective academic struggles has been disconfirmed by 
previous studies (Fass-Holmes \& Vaughn, 2014, 2015). Now, the accompanying concern about widespread cheating has not been supported by the present study.

Two notable limitations must be taken into consideration. The first is that, since the present study focuses on a single university, the above findings' generalizability and interpretation are limited. Studies at other universities will be needed to determine generalizability. The second limitation is that this study's findings depend upon faculty members' and teaching assistants' diligence in filing AIV reports. Therefore, the present findings could represent underestimates. Underreporting could happen due to faculty members' and/or teaching assistants' stress, lack of courage, time constraints, concern about retaliation or a legal challenge, and beliefs that cheating students would fail anyway or that offenders would not get caught (Keith-Spiegel, Tabachnick, Whitley, \& Washburn, 1998; Schneider, 1999). If underreporting actually did happen at the University, the percentage of international students with AIVs could be considerably higher than indicated in this article.

\section{IMPLICATIONS}

The almost six-fold increase in the number of the University's international students who have been reported for AIVs from 2009-10 ( $\mathrm{N}=35)$ to 2013$14(\mathrm{~N}=203)$ has administrative implications regarding workload. This increase translates into increased workload for faculty, administrators, and staff. If the present results are underestimates due to underreporting, the impact on workload could be even greater. Additional research will be necessary to measure the extent of AIV underreporting, in order to gain a more accurate determination of how many of the University's international students do cheat and how to distribute the resulting workload.

The possibility that the present results are underestimates due to underreporting has policy implications regarding graduation and retention. International students reported and expelled for AIVs were barred from returning to the University and thus their graduation rate was $0.0 \%$. If the University resolved underreporting and the number of international students eligible for expulsion increased beyond the value observed in this study, the resulting impact on graduation and retention could have serious accountability consequences (Cook \& Pullaro, 2010; Gold \& Albert, 2006). Therefore, additional studies extending the present study's measurement of the degree to which expulsions for cheating negatively impact graduation and/or retention rates should be conducted, and the University's current policies' and programs' efficacy for controlling AIVs should be evaluated.

The present findings additionally have theoretical implications for Bertram Gallant's (2008) organizational strategy which addresses cheating 
by focusing on teaching and learning rather than students' conduct and character. The University has employed this strategy, shifting at least some of its efforts from policing and deterring student cheating to ensuring student learning. One implication relates to this strategy's prediction that the number of reported international students should decrease (or at least remain stable) over years. The present study instead showed that the University's number of international students reported for AIVs increased almost six-fold over the five academic years. The disparity between the organizational strategy's prediction and the present results could be even greater if AIVs have been largely underreported by faculty and/or teaching assistants (Keith-Spiegel et al., 1998; Schneider, 1999). Another implication is that the University's implementation of the organizational strategy might require modification to maximize its efficacy in controlling students' cheating so that the number of AIVs decreases instead of the observed increases. A possible modification would be to repeat (at least once during each academic year) the segment on academic integrity included in the mandatory orientation for all newly admitted international students. In summary, Bertram Gallant's (2008) organizational strategy (as implemented at the University) either does permit an increasing rate of reported AIVs, or it is less effective than expected in controlling the University's AIV reporting rate.

Besides using an organizational strategy intended to shift efforts to ensuring student learning, the University also employs sanctions (expulsion and suspension) for reported AIVs. Sanctions constitute punishments, and are meant to deter or suppress cheating behavior rather than strengthen academic honesty (Maag, 2001). Punishment might be effective and/or desirable in controlling certain classroom behaviors or conditions (Maag, 2001). However, a potentially critical implication of using expulsion and suspension as punishments to deter undergraduate or graduate student cheating is that these sanctions have negative impacts on the graduation and retention rates which function as accountability indicators (Cook \& Pullaro, 2010; Gold \& Albert, 2006); students who are expelled or suspended (by definition) do not graduate and are not retained, respectively. Expulsion and suspension also negatively impact student satisfaction and engagement (Astin, 1984, 1993; Tinto, 2007); students who are expelled or suspended (by definition) are not satisfied or engaged. These negative impacts should prompt consideration to replace punishments with approaches that enhance (rather than impair) these key indicators of student success (Elliott \& Healy, 2001; Korobova \& Starobin, 2015; Kuh et al., 2006; Schertzer \& Schertzer, 2004; Therriault \& Krivoshey, 2014).

One potential approach to replacing punishments (expulsion and suspension) for reported AIVs would be to establish conditions in which cheating becomes unnecessary (rather than illegal) in order for international 
students to fulfill their educational goals. These students face diverse challenges while attending American universities; some are the same challenges facing domestic students (e.g., finances, health, housing conditions), others are unique (e.g., acculturative stress, cultural barriers, mandatory compliance with immigration regulations, lack of familiarity with American academic integrity standards and/or teaching methods) (Dorado \& Fass-Holmes, 2016; Hanassab \& Tidwell, 2002). An especially serious challenge which impacts the Asian students who are the University's largest group is English language (Lin \& Scherz, 2014; Mamiseishvili, 2012). English is particularly difficult for these students to master due to its considerable differences from their native languages (Wang, Koda, \& Perfetti, 2003), and consequently international students are at an extreme competitive disadvantage with domestic students (Kohn, 2007). If these students' competitive disadvantage due to their English weakness could be mitigated so that their need to resort to cheating was reduced (perhaps through researchbased accommodations; Francis, Rivera, Lesaux, Kieffer, \& Rivera, 2006; Fuchs \& Fuchs, 2001; Lin \& Scherz, 2014; Ofiesh, 2007), then punishments potentially could be eliminated in favor of praise (e.g., Delin \& Baumeister, 1994) or a to-be-invented reward system linked to social media that are popular among international students (e.g., Forbush \& Foucault-Welles, 2015; Saw, Abbott, \& Donaghey, 2013).

In conclusion, the present study's findings have administrative, policy, and theoretical implications. The administrative implications pertain to workload, the policy implications to the use of punishments, and the theoretical implications to the teaching and learning organizational strategy that addresses cheating by focusing on teaching and learning rather than students' behavior and character (Bertram Gallant, 2008). Despite this study's limitation to a single higher education institution, it could serve as a model for other American universities to replicate and use in making datadriven decisions about administration, policy, and organizational strategy which affect international students.

\section{REFERENCES}

Alschuler, A. S., \& Blimling, G. S. (1995). Curbing epidemic cheating through systemic change. College Teaching, 43(4), 123-125.

Asimov, N., \& Gutierrez, M. (2015). UC president, governor agree to freeze tuition for 2 years. Retrieved from http://www.sfgate.com/education/article/Napolitano-Jerry-Brown-strikedeal-on-UC-tuition-6263588.php

Asmussen, J. G. (2011). How might Governors improve college graduation rates? Retrieved from https://cerpp.usc.edu/files/2013/11/AERAFinalpaperASMUSSEN.pdf 
Astin, A. W. (1984). Student involvement: A developmental theory for higher education. Journal of College Student Personnel, 25, 297-308.

Astin, A. W. (1993). What matters in college? Four critical years revisited. San Francisco: Jossey-Bass.

Bertram Gallant, T. (2008). Academic integrity in the twenty-first century: A teaching and learning imperative. ASHE Higher Education Report, 33(5), $1-143$.

Bertram Galant, T., Binkin, N., \& Donohue, M. (2015). Students at risk for being reported for cheating. Journal of Academic Ethics, 13(3), 217-228.

Bista, K. (2011). Academic dishonesty among international students in higher education. In J. Miller \& J. Groccia (Eds.), To Improve the Academy: Vol. 30. Resources for Faculty, Instructional, and Organizational Development (pp. 159-172). San Francisco, CA: Jossey-Bass.

Callahan, D. (2010). Academic dishonesty: studies and reports, 1915-2010. Retrieved from http://www.cheatingculture.com/academicdishonesty/2010/10/7/academic-dishonesty- $\quad$ studies-and-reports-19152010.html

Cantwell, B. (2015). Are international students cash cows? Examining the relationship between new international undergraduate enrollments and institutional revenue at public colleges and universities in the US. Journal of International Students, 5(4), 512-525.

Cook, B., \& Pullaro, N. (2010). College Graduation Rates: Behind the Numbers. Washington, D.C.: American Council on Education.

Delin, C. R., \& Baumeister, R. F. (1994). Praise: More than just social reinforcement. Journal for the Theory of Social Behaviour, 24(3), 219-241

DiPietro, M. (2010). Theoretical frameworks for academic dishonesty. In L. B. Nilson \& J. E. Miller (Eds.), To Improve the Academy: Vol. 28. Resources for Faculty, Instructional, and Organizational Development (pp. 250-262). San Francisco, CA: Jossey-Bass.

Dorado, D. A. L., \& Fass-Holmes, B. (2016). Academic achievement and demographics of international undergraduates. In K. Bista \& C. Foster (Eds.), Exploring the Social and Academic Experiences of International Students in Higher Education Institutions (pp. 227-252). Hershey, PA: IGI Global.

Elliott, K. M., \& Healy, M. A. (2001). Key factors influencing student satisfaction related to recruitment and retention. Journal of Marketing for Higher Education, 10(4), 1-11. DOI: 10.1300/J050v10n04_01

Fass-Holmes, B., \& Vaughn, A. A. (2014). Are international undergraduates struggling academically? Journal of International Students, 4(1), 60-73.

Fass-Holmes, B., \& Vaughn, A. A. (2015). Evidence that international undergraduates can succeed academically despite struggling with English. Journal of International Students, 5(3), 228-243.

Forbush, E., \& Foucault-Welles, B. (2015). Social media use and adaptation among Chinese students beginning to study in the United States. International Journal of Intercultural Relations, 50, 1-12. DOI: 10.1016/j.ijintrel.2015.10.007

Francis, D., Rivera, M., Lesaux, N., Kieffer, M., \& Rivera, H. (2006). Practical Guidelines for the Education of English Language Learners: Research- 
Based Recommendations for the Use of Accommodations in Large-Scale Assessments. Portsmouth, N.H.: RMC Research Corporation, Center on Instruction.

Fuchs, L. S., \& Fuchs, D. (2001). Helping teachers formulate sound test accommodation decisions for students with learning disabilities. Learning Disabilities Research \& Practice, 16(3), 174-181

Gold, L., \& Albert, L. (2006). Graduation rates as a measure of college accountability. American Academic, 2(1), 89-106.

Grimes, P. W. (2004). Dishonesty in academics and business: A cross-cultural evaluation of student attitudes. Journal of Business Ethics, 49(3), 273-290.

Hanassab, S., \& Tidwell, R. (2002). International students in higher education: identification of needs and implications for policy and practice. Journal of Studies in International Education, 6(4), 305-322.

Hayes, N., \& Introna, L. D. (2005). Cultural values, plagiarism, and fairness: When plagiarism gets in the way of learning. Ethics \& Behavior, 15(3), 213-231.

Institute of International Education. (2014). Open Doors data international students: leading institutions by institutional type 2013/14. Retrieved from http://iie.org/Research-and-Publications/Open-Doors/Data/InternationalStudents/Leading-Institutions-By-Institutional-Type/2013-14

Institute of International Education. (2015a). Open Doors data international students: leading institutions by institutional type 2014/15. Retrieved from http://iie.org/Research-and-Publications/Open-Doors/Data/InternationalStudents/Leading-Institutions-By-Institutional-Type/2014-15

Institute of International Education. (2015b). Open Doors data international students: enrollment trends 1948-2015. Retrieved from http://www.iie.org/Research-and-Publications/Open-

Doors/Data/International-Students/Enrollment-Trends/1948-2015

Institute of International Education. (2015c). Open Doors data international students: new international enrollment. Retrieved from http://www.iie.org/Research-and-Publications/Open-

Doors/Data/International-Students/New-International-Enrollment/2004-15

Institute of International Education. (2015d). Open Doors 2010 fast facts. Retrieved from http://www.iie.org/en/Research-andPublications/ /media/Files/Corporate/Open-Doors/Fast-

Facts/Fast\%20Facts\%202010.ashx

Institute of International Education. (2015e). Open Doors data international students: all places of origin. Retrieved from http://iie.org/Research-andPublications/Open-Doors/Data/International-Students/All-Places-ofOrigin/2013-15

Kahn, W. A. (1990). Psychological conditions of personal engagement and disengagement at work. Academy of Management Journal, 33(4), 692-724.

Keith-Spiegel, P., Tabachnick, B. G., Whitley, Jr., B. E., \& Washburn, J. (1998). Why professors ignore cheating: Opinions of a national sample of Psychology instructors. Ethics \& Behavior, 8(3), 215-227.

Kohn, A. (2007). Who's cheating whom? Phi Delta Kappan, 89(2), 89-97.

Korobova, N., \& Starobin, S. S. (2015). A comparative study of student engagement, satisfaction, and academic success among international and American students. Journal of International Students, 5(1), 72-85 
Kuh, G. D. (2003). What we're learning about student engagement from NSSE: Benchmarks for effective educational practices. Change: The Magazine of Higher Learning, 35(2), 24-32. DOI: 10.1080/00091380309604090

Kuh, G. D., Kinzie, J., Buckley, J. A., Bridges, B. K., \& Hayek, J. C. (2006). What Matters to Student Success: A Review of the Literature. Washington, D.C.: National Postsecondary Education Cooperative.

Lang, J. M. (2013). Cheating Lessons-Learning from Academic Dishonesty. Cambridge, MA: Harvard University Press.

Lin, S-Y., \& Scherz, S. D. (2014). Challenges facing Asian international graduate students in the US: Pedagogical considerations in higher education. Journal of International Students, 4(1), 16-33.

Lu, S., \& Hunt, K. (2015). Fraud frenzy? Chinese seek U.S. college admission at any price. Retrieved from http://www.cnn.com/2015/07/12/asia/chinaeducation-agencies/

Lupton, R. A., Chapman, K. J., \& Weiss, J. E. (2010). A cross-national exploration of business students' attitudes, perceptions, and tendencies toward academic dishonesty. Journal of Education for Business, 75(4), 231-235.

Maag, J. W. (2001). Rewarded by punishment: Reflections on the disuse of positive reinforcement in schools. Exceptional Children, 67(2), 173-186.

Mamiseishvili, K. (2012). International student persistence in U.S. postsecondary institutions. Higher Education, 64(1), 1-17.

McCabe, D. L., Butterfield, K. D., \& Treviño, L. K. (2012). Cheating in CollegeWhy Students Do It and What Educators Can Do About It. Baltimore, MD: Johns Hopkins University Press.

McCabe, D. L., Feghali, T., \& Abdallah, H. (2008). Academic dishonesty in the Middle East: Individual and contextual factors. Research in Higher Education, 49(5), 451-467.

Mitchell, M., Palacios, V., \& Leachman, M. (2014). Most states fund higher ed at pre-recession levels. Retrieved from http://www.cbpp.org/research/statesare-still-funding-higher-education-below-pre-recession-

levels?fa=view\&id=4135

Mori, S. (2000). Addressing the mental health concerns of international students. Journal of Counseling \& Development, 78(2), 137-144.

Murdock, T. B., \& Anderman, E. M. (2006). Motivational perspectives on student cheating: toward an integrated model of academic dishonesty. Educational Psychologist, 41(3), 129-145. DOI: 10.1207/s15326985ep4103_1

National Survey of Student Engagement. (2015). NSSE 2015 snapshot. Retrieved from

http://nsse.indiana.edu/2015_Institutional_Report/pdf/NSSE15\%20Snapsh ot\%20(NSSEville\%20State).pdf

Nylander, J. (2015). How Chinese students are 'cheating' to get into U.S. universities. Retrieved from http://www.forbes.com/sites/jnylander/2015/07/13/how-chinese-studentsare-cheating-to-get-into-u-s-universities/

Obama, B. (2009). State of the Union Address. Retrieved from http://stateoftheunionaddress.org/2009-barack-obama 
Ofiesh, N. S. (2007). Math, science, and foreign language: Evidence-based accommodation decision making at the postsecondary level. Learning Disabilities Research \& Practice, 22(4), 237-245.

Qi, L. (2015). U.S. schools expelled 8,000 Chinese students. Retrieved from http://blogs.wsj.com/chinarealtime/2015/05/29/u-s-schools-expelled-8000chinese-students-for-poor-grades-cheating/

Redden, E. (2015). In China, no choice but to cheat? Retrieved from https://www.insidehighered.com/news/2015/07/09/admissions-processbroken-chinese-students

Saw, G., Abbott, W., \& Donaghey, J. (2013). Social media for international students-it's not all about Facebook. Retrieved from http://epublications.bond.edu.au/cgi/viewcontent.cgi?article=1034\&context =library_pubs

Schertzer, C. B., \& Schertzer, S. M. B. (2004). Student satisfaction and retention: A conceptual model. Journal of Marketing for Higher Education, 14(1), 7991. DOI: 10.1300/J050v14n01_05

Schneider, A. (1999). Why professors don't do more to stop students who cheat. Retrieved from http://chronicle.com/article/Why-Professors-Dont-DoMor/25673/

Sherry, M., Thomas, P., \& Chui, W. H. (2010). International students: a vulnerable student population. Higher Education, 60(1), 33-46.

Therriault, S. B., \& Krivoshey, A. (2014). College Persistence Indicators Research Review. Washington D.C.: American Institutes for Research.

Tinto, V. (1975). Dropout from higher education: A theoretical synthesis of recent research. Review of Educational Research, 45(1), 89-125. doi:10.3102/00346543045001089

Tinto, V. (2007). Research and practice of student retention: What next? Journal Of College Student Retention Research, 8(1), 1-19.

U.S. Department of Education. (2011). Vice President Biden issues call to action to boost college graduation rates nationwide. Retrieved from http://www.ed.gov/news/press-releases/vice-president-biden-issues-callaction-boost-college-graduation-rates-nationwide

U.S. Department of State. (n.d.). Directory of visa categories. Retrieved from https://travel.state.gov/content/visas/en/general/all-visacategories.html

U.S. News \& World Report. (2015). Top public schools national universities. Retrieved from http://colleges.usnews.rankingsandreviews.com/bestcolleges/rankings/national-universities/top-public

Vaughn, A. A., Bergman, M., \& Fass-Holmes, B. (2015). Nonresident undergraduates' performance in English writing classes-hierarchical linear modeling analysis. Journal of International Students, 5(4), 319-333.

Veiga, F. H, Galvão, D., Almeida, A., Carvalho, C., Janeiro, I., Nogueira, J., Conboy, J., Melo, M., Taveira, M. C., Festas, M. I., Bahia, S., Caldeira, S., \& Pereira, T. (2012). Students' engagement in school: a literature review. In M. F. Patrício, L. Sebastião, J. M. Justo, \& J. Bonito (Eds.), Da Exclusão à Excelência: Caminhos Organizacionais para a Qualidade da Educação (pp. 1136-1149). Montargil, Portugal: Associação da Educação Pluridimensional e da Escola Cultural. 
Wang, M., Koda, K., \& Perfetti, C. A. (2003). Alphabetic and nonalphabetic L1 effects in English word identification: a comparison of Korean and Chinese English L2 learners. Cognition, 87(2), 129-149. doi:10.1016/S00100277(02)00232-9

Whitley, B. E., Jr. (1998). Factors associated with cheating among college students: A review. Research in Higher Education, 39(3), 235-274.

Whitley, B. E. Jr., \& Keith-Spiegel, P. (2001). Academic integrity as an institutional issue. Ethics \& Behavior, 11(3), 325-342.

Wideman, M. A. (2008). Academic dishonesty in postsecondary education: a literature review. Transformative Dialogues: Teaching \& Learning Journal, 2(1), 1-12.

Zhao, C-M., Kuh, G. D., \& Carini, R. M. (2005). A comparison of international student and American student engagement in effective educational practice. Journal of Higher Education, 76(2), 209-231.

BARRY FASS-HOLMES, PhD, is the Analytical Studies Coordinator for the International Students \& Programs Office in the International Center at the University of California, San Diego. He studies international students' academic achievement. Email: bfholmes@ucsd.edu 